\title{
Brazilian Nursing and Psychology students' visits to patients with amyotrophic lateral sclerosis: prospective analysis
}

\author{
Visitas de estudantes brasileiros de Enfermagem e Psicologia a pessoas com esclerose \\ amiotrófica lateral: análise prospectiva \\ Antonio Geraldo ABREU FILHO',2, Leila Salomão Plata Cury TARDIVO', Acary Souza Bulle OLIVEIRA², Helga \\ Cristina Almeida da SILVA²
}

\begin{abstract}
Amyotrophic lateral sclerosis (ALS) is a neurodegenerative disease without a cure, but multidisciplinary treatment can maintain the quality of life (QOL) of persons with ALS (PALS). Despite health professionals possibly being affected by ALS in their care roles, little is known about the impact of ALS care on these professionals. Objective: To analyze the effects of interactions between PALS and Nursing/Psychology students. Methods: Over 12 weeks, 16 student pairs performed weekly 60-minute home visits to 16 PALS. Instruments used for analyses were the McGill Quality of Life Questionnaire for the PALS; and the Draw-a-Person test and the Desiderative Questionnaire for the students. All instruments were applied twice: at the beginning (pre-first visit) and at the end of the study (post-12 visits). Results: After 12 weeks, there was not a significant change in total QOL or its five domains (existential wellbeing, physical wellbeing, psychological wellbeing, physical symptoms, and support). Existential wellbeing/support domains contributed most to the QOL of the PALS (pre-first visit and post-12 visits). Students showed anxiety/impulsivity but preserved adequacy to reality, logical thinking and global perception with regard to the PALS. We found that students were psychologically fragile in some subgroups/moments. Conclusions: Students' visits to PALS may contribute to the maintenance of the QOL of the patients. Additionally, visits, with psychological support for the students, seem safe and could contribute to the students' psychological maturation as health professionals. Additional psychological support may be necessary for some students in fragile subgroups/moments.
\end{abstract}

Keywords: Amyotrophic lateral sclerosis; nursing; psychology; quality of life.

\section{RESUMO}

Esclerose lateral amiotrófica (ELA) é doença neurodegenerativa sem cura, mas tratamento multidisciplinar pode manter qualidade de vida (QOL). Embora profissionais de saúde possam ser afetados pela atuação na ELA, pouco é conhecido sobre impacto nesses profissionais. Objetivo: Analisar efeitos da interação entre pessoas com ELA e estudantes de Enfermagem e de Psicologia. Métodos: Durante 12 semanas, 16 pares de estudantes realizaram visitas domiciliares semanais de 60 minutos a 16 pessoas com ELA. Instrumentos utilizados nas análises foram McGill QOL para pessoas com ELA e Desenhe uma Pessoa e Questionário Desiderativo para estudantes, aplicados no início (pré-primeira visita) e final do estudo (pós-12 visitas). Resultados: Após 12 semanas, não houve alteração significativa na QOL total ou nos seus cinco domínios (bem-estar existencial, bem-estar físico, bem-estar psicológico, sintomas físicos e suporte). Bem-estar existencial e suporte contribuíram mais para QOL de pessoas com ELA (pré-primeira visita e pós-12 visitas). Estudantes apresentaram impulsividade/ansiedade, mas preservaram adequação à realidade, pensamento lógico e visão global da pessoa com ELA. Detectamos que estudantes estavam psicologicamente frágeis em alguns subgrupos/momentos: estudantes de Enfermagem pré-primeira visita, estudantes de Psicologia pós-12 visitas, estudantes do quinto semestre do respectivo curso, estudantes com 23 anos ou menos, e estudantes do sexo masculino pós-12 visitas. Conclusões: Visitas de estudantes a pessoas com ELA podem contribuir para a manutenção da QOL. Visitas com apoio psicológico parecem seguras e podem contribuir para amadurecimento psicológico dos estudantes como profissionais de saúde. Suporte psicológico adicional pode ser necessário para alguns estudantes em subgrupos/momentos frágeis.

Palavras-chave: Esclerose amiotrófica lateral; enfermagem; psicologia; qualidade de vida.

\footnotetext{
'Universidade de São Paulo, APOIAR (Laboratório de Saúde Mental e Clínica de Psicologia Social), São Paulo SP, Brasil;

ZUniversidade Federal de São Paulo, Escola Paulista de Medicina, Departmento de Neurologia, São Paulo SP, Brasil.

Oliveira ASB and Silva HCA provided equal contributions to this study.

Antonio Geraldo Abreu Filho (iD https://orcid.org/0000-0001-6591-4899; Leila Salomão Plata Cury Tardivo (iD) https://orcid.org/0000-0002-8391-0610; Acary Souza Bulle Oliveira iD https://orcid.org/0000-0002-6986-4937; Helga Cristina Almeida da Silva (iD) https://orcid.org/0000-0002-9372-7019

Correspondence: Helga Cristina Almeida da Silva; UNIFESP; Rua Napoleão de Barros, 715 / 5 andar; 04024-002 São Paulo SP, Brasil; Email: halsilva@uol.com.br Conflict of interest: There is no conflict of interest to declare.

Support: This study was financed in part by the Coordenação de Aperfeiçoamento de Pessoal de Nivel Superior - Brasil (CAPES) - Finance Code 001.

Received 15 March 2019; Received in final form 24 July 2019; Accepted 28 July 2019
} 
Amyotrophic lateral sclerosis (ALS) is a neurodegenerative disease without a cure, but multidisciplinary treatment improves patient survival and quality of life (QOL) ${ }^{1}$. Psychological support for persons with ALS (PALS) and all those involved in patient care may ameliorate multiple problems, such as suicidal intent (reported in 18.9-56\% of PALS, with the lowest values when patients feel supported), decreased PALS/caregivers' QOL, and multidisciplinary team burnout syndrome $e^{1,2,3,4,5,6,7}$. However, few researchers have addressed the impact of the care of patients with incurable neurodegenerative diseases, such as ALS, on health professionals, in particular students. Volunteer university students can help PALS, with good acceptance by both parties, but there has been no previous research on the psychological consequences $^{8,9}$. As far as we have been able to determine, no study has evaluated the psychological impact of ALS care on students/health professionals in Brazil. Moreover, there is little information on the QOL of Brazilian PALS as measured by the McGill Quality of Life Questionnaire. To the best of our knowledge, no one has studied how PALS' QOL could be affected by visits from university students and, therefore, this study could provide specific information for this population. Therefore, the aim of this study was to prospectively analyze the effects of interactions between PALS and nursing/psychology students.

\section{METHODS}

\section{Participants}

PALS: Sixteen PALS were referred by ALS outpatient clinics or the National ALS Association. The inclusion criterion was a diagnosis of ALS according to El Escorial criteria (clinically definite, probable, or possible ALS). A psychologist visited each patient twice to explain the research and apply the McGill Quality of Life Questionnaire, at the beginning (pre-first visit) and the end of the investigation (post-12 visits).

Students: After project disclosure in the two schools (nursing and psychology) and a 12-hour educational program about ALS, 32 students agreed to participate (16 nursing students, 16 psychology students) and formed pairs from the same school (nursing or psychology). Each pair was maintained throughout the 12 weeks. The students' psychological dynamics were assessed twice, at the beginning (pre-first visit) and the end of the research (post-12 visits), with two projective instruments: the Draw-a-Person test and the Desiderative Questionnaire.

\section{Procedures}

We prospectively investigated the effects of 12 home visits to PALS performed weekly by pairs of students. Each pair visited the same PALS during all of the 12 weeks. All participants signed a written informed consent form approved by the Ethics Committee of the Federal University of São Paulo. No student or PALS dropped out of the visit process.

A psychologist contacted each PALS and informed them of the students' names before the first visit, and then the students began their home visits. Visits offered listening/support to PALS, and the PALS could suggest activities to students, except for any intervention related to their corresponding school (nursing/psychology). Every week, the psychologist discussed the visits with all of the students, during which he provided guidance on attitudes, gave support, and explained the feelings shown by the PALS and the students, and this process was based on Kleinian analysis ${ }^{10}$.

\section{Assessment instruments}

McGill Quality of Life Questionnaire: The questionnaire assesses the present situation (past two days) of a patient's life and how they addressed situations related to existential wellbeing, physical wellbeing, psychological wellbeing, physical symptoms, and support. The 16 items are scored from 0 -10, where 0 indicates the worst possible situation and 10 , the best one ${ }^{11}$.

Draw-a-Person test with a thematic design: Students were asked to "Draw a person with ALS and discuss the drawing". The graphic expression is based on thematic apperception, that is, how individuals create personal expressions related to internal/external reality and show emotional reactions ${ }^{12,13}$. The analysis of the Draw-a-Person test data was performed according to criteria formulated by Machover $^{12}$, in 1978, which prioritizes formal features (expressed traits) in human figure drawing, revealing self-images ${ }^{12-15}$.

Desiderative Questionnaire or Pigem's test: The Desiderative Questionnaire aims to investigate and evaluate the adequacy to reality, logical thinking, affective manifestations and defense mechanisms ${ }^{16-23}$. Adequacy to reality was evaluated by an average reaction time to the Desiderative Questionnaire, type and sequence of responses, presence of anthropomorphisms in responses, and need of induction (external help due to the inability to respond to a given question). Logical thinking was tested by content/organization of thoughts and distinctions between internal and external reality. Affective manifestation was analyzed by degree of self-perception, associations and interactions of given responses.

The Desiderative Questionnaire comprises six pairs of questions, three of which are choices (e.g., +1: if you could not be a person, what would you like to be? Why?) and three are rejections (e.g., -1: if you could not be a person, what would you dislike being? Why?). Each question investigates individual fantasies/desires, either in its positive (choice) or negative (rejection) form. It is expected that choices are made in the animal kingdom first, followed by plants, and then by 
inanimate objects (Figure 1). The expected reaction time is approximately 10-30 seconds per question ${ }^{22}$. Common answers are those present in at least $15 \%$ of the sample, i.e., 14 when considering the three choices (negative or positive) in our group of 32 students $^{20}$. For statistical analysis of the Desiderative Questionnaire, each answer was scored from $1-6$, according to the increased distance from the expected ideal answer: animal kingdom: 1; plant kingdom: 2; inanimate kingdom: 3; shapeless: 4 (e.g.: water, feelings); nonexistent shapes: 5 (anthropomorphic imaginary beings, e.g., vampires); no answer: 6 .

\section{Data analysis}

Data were analyzed with the Kolmogorov-Smirnov test. Parametric data are expressed as the mean/standard deviation of the sample and were analyzed with a paired t-test or an unpaired t-test with Welch correction. Nonparametric data are expressed as median/quartiles and were analyzed with a Wilcoxon test, a Friedman test with Miller-Dunn post hoc test or a Mann-Whitney test. Categorical data are expressed as absolute/relative frequencies and analyzed by the chi-square test or McNemar's test. Correlations were assessed with Spearman's test. In all analyses, $\alpha$ risk $\leq 0.05$ and $\beta$ risk $\leq 0.20$ were used. Statistical analyses were performed using a standard computer software package (GraphPad Prisma, GraphPad Software; San Diego, CA, USA). All research materials related to this paper are archived and can be accessed by contacting the corresponding author.

\section{RESULTS}

\section{PALS demographic data}

The mean age of the 16 patients was $53.9 \pm 15.1$ years; eight were male. The time since diagnosis of ALS was $19.7 \pm 16.2$ months (two months to four years). All 16 patients had sporadic forms of the disease. Six patients had definite, five possible, and five probable ALS; after 12 weeks, at the end of the study, two ALS patients with possible ALS had progressed to probable ALS. None of the patients used ventilator assistance or had a gastrostomy/tracheostomy during this study.

\section{Students' demographic data}

The mean age of the 32 students was $23 \pm 5.72$ years old, and $22(68.7 \%)$ were female. There was no statistically significant difference between the age or sex of the psychology and nursing students (age: $23.6 \pm 5.0$ vs. $23.3 \pm 6.5$ years old respectively, Mann-Whitney test, p 0.584; sex: 12 (75\%) vs. 10 (62.5\%) female, respectively, chi-square test, $\mathrm{p}=0.445)$. The duration of the psychology and nursing courses is five years (10 semesters) and four years (eight semesters), respectively. The mean length of studies of the 32 students was $4.43 \pm 1.75$ semesters; with $5.5 \pm 1.5$ and $3.4 \pm 1.2$ semesters for the psychology and nursing courses, respectively ( $\mathrm{p}<0.001$; unpaired t-test).

\section{McGill Quality of Life Questionnaire scores of ALS patients}

The median total scores at the first (pre-visit) and second evaluation (12th post-visit) showed no significant difference (median/interquartile range 25-75\%: 6.26/4.37-7.44 vs 4.95/4.01-7.07 respectively, $\mathrm{p}=0.14$; Wilcoxon test) nor did the median of each one of the five domains ( $p=$ nonsignificant; Wilcoxon test) (Figure 2). The physical symptoms domain presented the worst scores, while existential wellbeing and support showed the best scores (Figure 2). There was a decreasing tendency in the total score and in four of the five domains, whereas psychological wellbeing showed a tendency to increase.

\section{Psychological weekly meeting and Draw-a-Person test for the students}

Students progressively incorporated and developed ideas of support, receptiveness, observation and humanized listening. For the entire group (psychology and nursing), before and after visits, there was a predominance of drawings of a male, a fully-dressed figure, front view, nonsimple line, sitting position, and no reference to the PALS (Table 1). After the visits, only the number of drawings of female figures showed a significant increase in the sample as a whole ( $p=0.039$; McNemar's test). The seven students who shifted to drawing a female figure were female. A comparison of the first and second drawings of the human figure revealed no difference between the psychology and nursing groups ( $\mathrm{p}$ = nonsignificant; chi-square test), with progress in lines and/or context in the majority of the group (13 students, 40.6\%; Figure $3 \mathrm{~A}$ and B), regression in 11 students (34.3\%; Figure $3 \mathrm{C}$ and D), and stability in eight students (25\%).

\begin{tabular}{|lr|}
\hline Choices & Questions and expected answers \\
\hline+1 & If you could not be a person, what else would you like to be? Why? Expected response: Animal (e.g.: bird) \\
+2 & If you could not be a person, animal or plant, what else would you like to be? Why? Expected response: Inanimate object (e.g.: diamond) \\
+3 & If you could not be a person, what would you least like to be? Why? Expected response: Animal (e.g.: rat) \\
-1 & If you could not be a person or animal, what would you least like to be? Why? Expected response: Plant (e.g.: cactus) \\
-2 & If yould not be a person, animal or plant, what would you least like to be? Why? Expected response: Inanimate object (e.g.: stone) \\
-3 &
\end{tabular}

Figure 1. Desiderative Questionnaire: choices/questions and expected answers. 


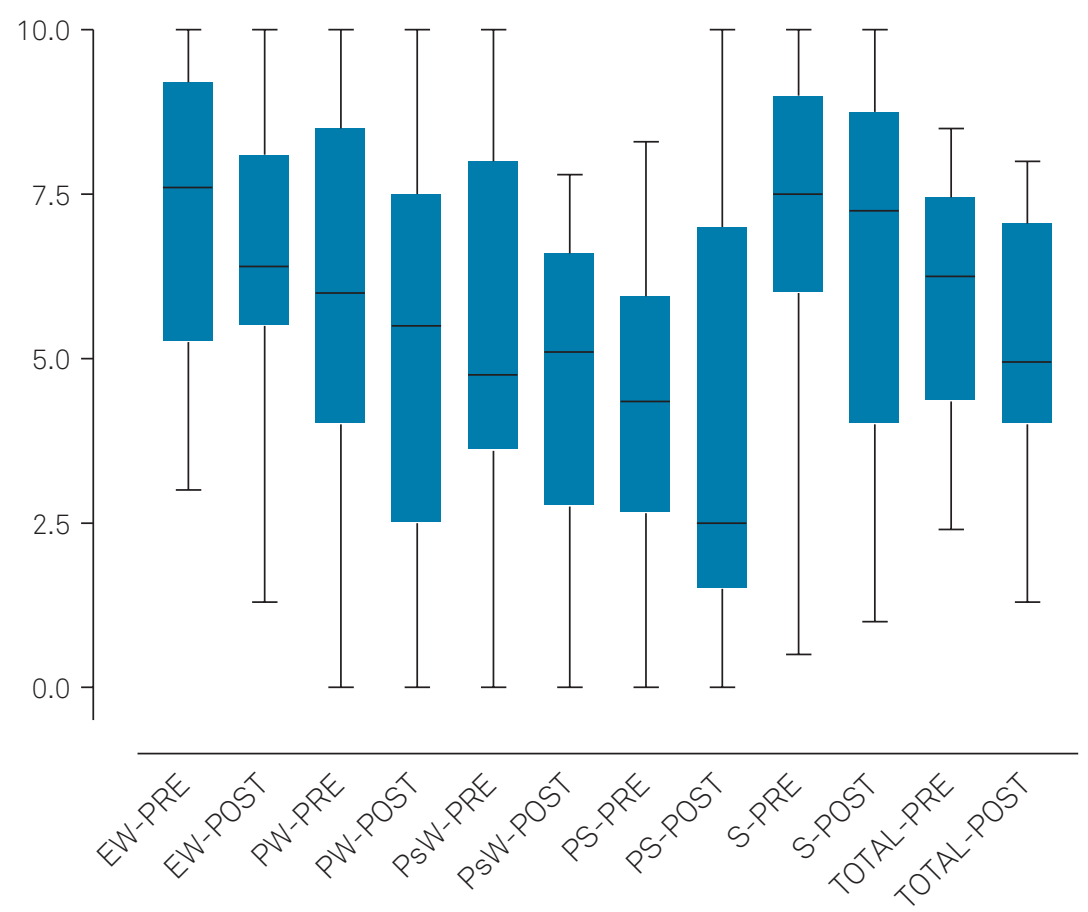

PRE: pre-visit; POST: post-visit; EW: existential wellbeing; PW: physical wellbeing; PsW: psychological wellbeing; PS: physical symptoms; S: support.

Figure 2. McGill Quality of Life Questionnaire scores (median/percentiles) of patients with ALS, pre- and post-visits, on the five domains (existential wellbeing, physical wellbeing, psychological wellbeing, physical symptoms and support).

Table 1. Draw-a-Person: before and after visit

\begin{tabular}{|c|c|c|c|c|c|}
\hline \multirow{2}{*}{ Variable } & \multicolumn{2}{|c|}{ Psychology $(n=16)$} & \multicolumn{2}{|c|}{ Nursing $(n=16)$} & \multirow{2}{*}{$\begin{array}{c}\text { McNemar's test } \\
\mathrm{p} \text {-value }\end{array}$} \\
\hline & Before & After & Before & After & \\
\hline Male sex & $11(68.7 \%)$ & $6(37.6 \%)$ & $7(43.7 \%)$ & $7(43.7 \%)$ & 0.302 \\
\hline Female sex & $2(12.6 \%)$ & $7(43.7 \%)$ & $0(0.0 \%)$ & $2(12.6 \%)$ & $0.039^{a}$ \\
\hline Sex not indicated & $3(18.7 \%)$ & $3(18.7 \%)$ & $9(56.3 \%)$ & $7(43.7 \%)$ & 0.607 \\
\hline Part of the body & $3(18.7 \%)$ & $1(6.2 \%)$ & $1(6.2 \%)$ & $1(6.2 \%)$ & 0.687 \\
\hline Full figure & $13(81.3 \%)$ & $15(93.8 \%)$ & $15(93.8 \%)$ & $15(93.8 \%)$ & 0.453 \\
\hline Lateral view & $2(12.6 \%)$ & $1(6.2 \%)$ & $0(0.0 \%$ & $2(12.6 \%)$ & 1.000 \\
\hline Front view & $14(87.4 \%)$ & $15(93.8 \%)$ & $16(100 \%)$ & $14(87.4 \%)$ & 1.000 \\
\hline Simple lines & $5(31.2 \%)$ & $4(25.0 \%)$ & $5(31.3 \%)$ & $5(31.3 \%)$ & 1.000 \\
\hline Non-simple lines & $11(68.8 \%)$ & $12(75.0 \%)$ & $11(68.7 \%)$ & $11(68.7 \%)$ & 1.000 \\
\hline Standing & $5(31.3 \%)$ & $6(37.6 \%)$ & $6(37.6 \%)$ & $4(25.0 \%)$ & 1.000 \\
\hline Sitting & $9(56.1 \%)$ & $7(43.7 \%)$ & $7(43.7 \%)$ & $8(50 \%)$ & 1.000 \\
\hline Lying & $2(12.6 \%)$ & $3(18.7 \%)$ & $3(18.7 \%)$ & $4(25.0 \%)$ & 0.727 \\
\hline Dressed & $16(100 \%)$ & $15(93.8 \%)$ & $12(75 \%)$ & $13(81.3 \%)$ & 0.267 \\
\hline Naked & $0(0.0 \%)$ & $0(0.0 \%)$ & $4(25 \%)$ & $0(0.0 \%)$ & 1.000 \\
\hline Transparent clothing & $0(0.0 \%)$ & $1(6.2 \%)$ & $0(0.0 \%)$ & $3(18.7 \%)$ & 1.000 \\
\hline Reference to the patient & -- & $7(43.7 \%)$ & -- & $2(12.6 \%)$ & $X^{2} 0.113$ \\
\hline Non-reference to the patient & & $9(56.3 \%)$ & & $14(87.4 \%)$ & \\
\hline Better & -- & $8(50.0 \%)$ & -- & $5(31.3 \%)$ & 0.413 \\
\hline Worse & -- & $4(25.0 \%)$ & -- & $7(43.7 \%)$ & \\
\hline Unchanged & -- & $4(25.0 \%)$ & -- & $4(25.0 \%)$ & \\
\hline
\end{tabular}

\section{Desiderative questionnaire}

Type and sequence of answers: For the first positive choice, the expected answer (animal kingdom) was the most frequent in 32 students before and after visits $(24(75 \%)$ and 21 (65.6\%), respectively) (Table 2). After the analysis of all three positive choices, the common answer before visits was bird $(\mathrm{n}=14)$ and after visits, tree $(\mathrm{n}=15)$. The corresponding reasons for the choices made were: for bird, the beauty or freedom, and for tree, the strength or ability to bear fruits. 
A

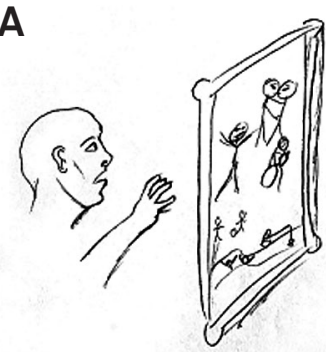

B

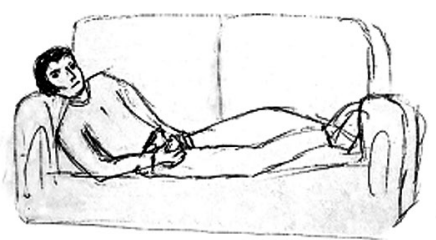

C

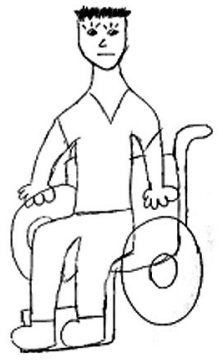

D

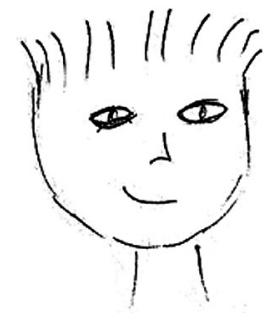

Reports of psychology and nursing students in the Draw-a-Person Test with a thematic design: there was progress in lines and/or context from Figure a to b, and regression from Figure c to d. Drawing a: "I think that a patient with ALS has some limitations that seem to ruin his life, as if meaningful subjects and life have ended when he realized he had ALS. In this picture, he observes his self-image through the ALS lens, which results in a darker view of life, with much suffering from now, while waiting for death". Drawing b: "Due to the advanced stage of the disease, this person with ALS cannot move - he stays in bed without moving his arms and legs, and requires assistance for these movements. Despite the reasons for suffering, there is still quality of life with the help of caregiver and multiprofessional team". Drawing c: "He's in a wheelchair - he lost the movement of his hands, arms, legs and feet. Only his head moves, but he is attentive and curious. His eyes are the window to his soul". Drawing d: "The disease has progressed - he only blinks and nothing else. He feels only his head, because his body does not exist anymore. He still is aware of his degeneration and thinks about how and when death will happen, while he lives alone with his suffering".

Figure 3. Comparison of the human figure drawings made by one psychology student (Figure a and b) and one nursing student (Figure c and d), before (left) and after visits (right) to ALS patients.

Table 2. Answers to the first positive choice of the Desiderative Questionnaire before and after visits.

\begin{tabular}{|c|c|c|c|c|}
\hline \multirow{2}{*}{ First choice } & \multicolumn{2}{|c|}{ Psychology } & \multicolumn{2}{|c|}{ Nursing } \\
\hline & Before $(n=16)$ & After $(n=16)$ & Before $(n=16)$ & After $(n=16)$ \\
\hline \multirow{6}{*}{ Animal kingdom } & Bird (6) & Bird (3) & Bird (5) & Cat (3) \\
\hline & $\operatorname{Dog}(1)$ & $\operatorname{Dog}(2)$ & $\operatorname{Dog}(3)$ & $\operatorname{Dog}(2)$ \\
\hline & Wolf (1) & Cat (1) & Jaguar (1) & Dolphin (2) \\
\hline & Whale (1) & Wolf (1) & Cat (1) & Horse (2) \\
\hline & Rabbit (2) & Rabbit (1) & Butterfly (1) & Butterfly (1) \\
\hline & Fish (1) & & Leopard (1) & Leopard (1) Lion (1) Whale (1) \\
\hline \multirow{3}{*}{ Plant kingdom } & Tree (2) & Tree (2) & Flower (1) & Flower (1) \\
\hline & Flower (1) & Flower (1) & & \\
\hline & & Plant (1) & & \\
\hline \multirow{4}{*}{ Inanimate kingdom } & House (1) & Book (1) & Star (1) & Book (1) \\
\hline & & Syringe (1) & Moon (1) & Divan (1) \\
\hline & & Stone (1) & Gun (1) & \\
\hline & & Boat (1) & & \\
\hline
\end{tabular}

Data expressed as absolute frequencies.

There was a significant difference in all six answers at each of the two moments, both before and after visits $(\mathrm{p}<0.0001$ and $\mathrm{p}<0.01$, respectively; Friedman test), and this result is the expected ideal answer. However, there was no difference between the answers before and after visits ( $p=$ nonsignificant; Wilcoxon test) (Table 3).
Failure to answer a question (characterized by partial/total inability to answer, or anthropomorphic/shapeless answers) was found for five students in the pre-visit and for one student in the post-visit. Failures of rationalization (the choice had no justification according to laws of formal logic, or the reasons presented did not justify the

Table 3. Answers to the Desiderative Questionnaire before and after visits (all students: psychology and nursing).

\begin{tabular}{|c|c|c|c|c|c|c|c|}
\hline \multirow{2}{*}{ Questions } & \multicolumn{3}{|c|}{ Before } & \multicolumn{3}{|c|}{ After } & \multirow{2}{*}{ Wilcoxon test } \\
\hline & $\mathrm{n}$ & Median & Quartiles & $\mathrm{n}$ & Median & Quartiles & \\
\hline+1 & 32 & 1.00 & $1.00-1.00$ & 32 & 1.00 & $1.00-2.00$ & 0.225 \\
\hline+2 & 32 & 2.00 & $2.00-3.00$ & 32 & 2.00 & $2.00-3.00$ & 0.758 \\
\hline+3 & 31 & 3.00 & $2.00-3.00$ & 32 & 2.00 & $2.00-3.00$ & 0.126 \\
\hline-1 & 31 & 3.00 & $1.00-3.00$ & 32 & 3.00 & $1.00-3.00$ & 0.259 \\
\hline-2 & 31 & 2.00 & $1.00-3.00$ & 32 & 2.00 & $1.00-3.00$ & 0.914 \\
\hline-3 & 30 & 2.00 & $1.75-2.00$ & 31 & 2.00 & $1.00-2.00$ & 0.124 \\
\hline Friedman test (columns) & & $p<0.0001$ & & & $p<0.01$ & & \\
\hline
\end{tabular}

Median values correspond to the answers to each question: 1 - animal, 2 - plant, 3 - inanimate, 4 - shapeless, 5 - nonexistent, 6 - no answer. 
choice made) were found for seven students in the pre-visit Desiderative Questionnaire and for five students in the postvisit Desiderative Questionnaire.

Answer time: Students had short reaction times (i.e., less than 10 seconds) in choices +1 (animal kingdom) and +2 (plant kingdom), both before and after visits. Nursing students showed a nonsignificant reduction of reaction time after visits, below 10 seconds, in choices +3 and -1 . In the full sample (psychology/nursing students), there was no significant difference in mean answer time for each choice, comparing pre- and post-visit values ( $\mathrm{p}$ = nonsignificant; paired Student's t-test) (Table 4).

There was no difference between the groups (psychology and nursing) in mean answer time for each choice, at both the pre- and post-visit (Table 5). However, a comparison of mean reaction time in each choice for the before and after visit per group (psychology or nursing students) found a significant reduction of answer time for the first affirmative choice (answer +1 ) of the psychology students ( $p=0.042$; paired t-test).

Answers versus variables: A significant difference was found among the six answers $(+1,+2,+3 /-1,-2,-3)$ in most subgroups, both before and after visits; this result was the expected ideal answer ( $\mathrm{p}<0.05$; Friedman test) (Table 6). This significant difference was absent in four subgroups: a) pre-visit: nursing students; and b) post-visit: male sex, psychology course, and students 23 years old or younger.

There was a significant change in some choices between before/after visits in the following subgroups: psychology students (first positive choice: worsening), students in the fourth semester or lower (third negative choice: worsening) and students in the fifth semester or higher ( first negative choice: improvement) (Wilcoxon test) (Table 7). In addition, the order relative to the first negative choice appeared inverted in the sample as a whole and in most subgroup analyses (inanimate objects: 3 , instead of animal kingdom: 1) except for female students after visits, nursing students both before and after visits, students older than 23 years both before and after visits, and students attending semesters higher than the fifth after visits.

\section{DISCUSSION}

\section{PALS and quality of life}

Most PALS in this study were in their sixth decade of life, similar to the characteristics of PALS worldwide, but there were fewer men than is usually reported ${ }^{24}$. For the PALS, quality of life provides the most global view, as its level may eventually stabilize despite their worsening physical condition ${ }^{25,26}$. Care provided by the multidisciplinary staff and access to an association of patients may explain the high scores of our patients in support/existential wellbeing domains ${ }^{27,28}$. The low score of the physical symptom domain reflected the patients' perception of their actual condition due to progressive loss of body functions ${ }^{29}$. However, scores in the domains of physical wellbeing and psychological wellbeing were in an intermediary position. Distinctions between the domains of

Table 4. Desiderative Questionnaire: answer time for all of the students (psychology and nursing) before and after visits. Time expressed in seconds.

\begin{tabular}{|c|c|c|c|c|c|c|}
\hline \multirow{2}{*}{ Choices } & \multirow{2}{*}{$n$} & \multicolumn{2}{|c|}{ Before } & \multicolumn{2}{|c|}{ After } & \multirow{2}{*}{$\begin{array}{c}\text { Paired Student's t-test } \\
\mathrm{p} \text {-value }\end{array}$} \\
\hline & & Mean & SD & Mean & SD & \\
\hline+1 & 32 & 5.8 & 4.7 & 5.4 & 4.9 & 0.503 \\
\hline+2 & 32 & 7.4 & 7.5 & 8.2 & 8.2 & 0.334 \\
\hline+3 & 31 & 10.2 & 9.3 & 10.1 & 10.6 & 0.601 \\
\hline-1 & 31 & 11.0 & 10.2 & 9.9 & 8.4 & 0.465 \\
\hline-2 & 31 & 17.3 & 18.4 & 20.4 & 21.4 & 0.271 \\
\hline-3 & 30 & 17.1 & 16.8 & 12.9 & 8.2 & 0.378 \\
\hline
\end{tabular}

Data expressed as the mean and standard deviation (SD) of the sample.

Table 5. Desiderative Questionnaire: answer time for each group of students (psychology and nursing) before and after visits. Time expressed in seconds.

\begin{tabular}{|c|c|c|c|c|c|c|c|c|c|c|}
\hline \multirow{3}{*}{ Choice } & \multicolumn{4}{|c|}{ Psychology } & \multicolumn{4}{|c|}{ Nursing } & \multirow{2}{*}{\multicolumn{2}{|c|}{$\begin{array}{c}\text { Unpaired t-test } \\
\mathrm{p} \text {-value }\end{array}$}} \\
\hline & \multicolumn{2}{|c|}{ Before } & \multicolumn{2}{|c|}{ After } & \multicolumn{2}{|c|}{ Before } & \multicolumn{2}{|c|}{ After } & & \\
\hline & Mean & SD & Mean & SD & Mean & SD & Mean & SD & Before & After \\
\hline+1 & 7.1 & 4.5 & 5.6 & 5.1 & 4.5 & 4.6 & 5.1 & 4.7 & 0.118 & 0.776 \\
\hline+2 & 4.9 & 3.7 & 7.7 & 5.9 & 9.2 & 9.6 & 8.9 & 11.3 & 0.086 & 0.703 \\
\hline+3 & 10.4 & 9.2 & 11.7 & 12.6 & 10.4 & 4.8 & 7.3 & 5.7 & 0.990 & 0.262 \\
\hline-1 & 11.8 & 11.1 & 11.5 & 9.1 & 12.8 & 13.3 & 7.2 & 6.7 & 0.815 & 0.157 \\
\hline-2 & 13.6 & 14.4 & 25.5 & 25.1 & 15 & 14.9 & 12 & 9.0 & 0.802 & 0.084 \\
\hline-3 & 19.2 & 24.1 & 11.7 & 7.2 & 24.7 & 17.6 & 15 & 9.6 & 0.493 & 0.297 \\
\hline
\end{tabular}

Data expressed as the mean and standard deviation (SD) of the sample. 
Table 6. Before and after visits subgroup analyses of answers to the six choices of the Desiderative Questionnaire: search for causal tendency.

\begin{tabular}{|c|c|c|c|c|c|c|}
\hline \multirow{3}{*}{ Variable } & \multicolumn{3}{|c|}{ Choice before } & \multicolumn{3}{|c|}{ Choice after } \\
\hline & \multicolumn{2}{|c|}{ Median (quartiles) } & \multirow{2}{*}{$\begin{array}{c}\text { Friedman } \\
\text { (all } 6 \text { choices) }\end{array}$} & \multicolumn{2}{|c|}{ Median (quartiles) } & \multirow{2}{*}{$\begin{array}{c}\text { Friedman } \\
\text { (all } 6 \text { choices) }\end{array}$} \\
\hline & $\begin{array}{c}\text { Positive } \\
\text { ( } 3 \text { choices) }\end{array}$ & $\begin{array}{c}\text { Negative } \\
\text { (3 choices) }\end{array}$ & & $\begin{array}{c}\text { Positive } \\
\text { ( } 3 \text { choices) }\end{array}$ & $\begin{array}{c}\text { Negative } \\
\text { ( } 3 \text { choices) }\end{array}$ & \\
\hline Male sex & $2(1-3 / 4)^{c}$ & $1 / 2(3 / 4-2)$ & p 0.007 & $2(1-2)$ & $2(3-2)$ & $p=0.664$ \\
\hline Female sex & $2(1-3)$ & $2(3-2)$ & p 0.009 & $2(1-2 / 3)$ & $2(1 / 2-2)$ & $p=0.005$ \\
\hline Psychology course & $2(1-3)$ & $1 / 2(3-2)$ & $p<0.0001$ & $2 / 3(1-2 / 3)$ & $2(3-2)$ & $p=0.164$ \\
\hline Nursing course & $2(1-3)$ & $2(1-2)$ & p 0.154 & $2(1-3)$ & $2(1-2)$ & $p<0.007$ \\
\hline At least $5^{\text {th }}$ semester ${ }^{\mathrm{a}}$ & $2(1-3)$ & $1 / 2(3 / 4-2)$ & $p<0.005$ & $3(1-2)$ & $1(3-2)$ & $p<0.005$ \\
\hline Older than 23 years ${ }^{b}$ & $2(1-3)$ & $3(3-2)$ & p 0.007 & $2 / 3(1-2 / 3)$ & $2(2-2)$ & $p=0.030$ \\
\hline 23 years old or younger & $2(1-2 / 3)$ & $2(3-2)$ & p 0.007 & $2(1-2)$ & $2(3-2)$ & $p=0.175$ \\
\hline
\end{tabular}

Median values correspond to the answers to each question or choice: 1 - animal, 2 - plant, 3 - inanimate, 4 - shapeless, 5 - nonexistent, 6 - no answer. a midpoint of the psychology course duration (fifth course semester); b mean age of the sample (23 years old); c the median of the three positive choices, at the time-point before visits for the male sex subgroup, showed the value 2 (plant kingdom), while quartiles $1-3 / 4$ indicate that the students remained between the animal kingdom (quartile 1, as the lower limit of variation) and the inanimate and shapeless areas (quartile 3/4, as the upper limit).

physical symptoms and physical wellbeing are based on the fact that a patient might exhibit troublesome symptoms, but the patient's physical wellbeing might be adequate to meet functional demands.

The absence of significant differences in the scores pre- and post-visits could be due to the short interval between the two assessments. Another possibility is that the tendency of improvement in the psychological wellbeing domain was compensated for by the worsening in the other domains, particularly the physical symptoms domain. The tendency of the psychological wellbeing domain score to increase could be explained by the students' visits. Previous studies have emphasized the provision of psychological support duringan ALS diagnosis announcement and throughout treatment ${ }^{29,30,31,32,33}$.

\section{Psychological weekly meeting and Draw-a-Person Test}

Suicide, reported in students attending health courses, was a concern of the authors during the study, but changes seen in students during the study suggests that visits to PALS, with psychological support, are safe and may contribute to the maturation of future professionals ${ }^{34}$.

In the Draw-a-Person test, the predominance of drawings of the male sex was unexpected, since each student was expected to draw a figure with his/her own sex; this was partially corrected in the post-visit drawing, with an increase of the female sex in the drawing ${ }^{12,15,35,36}$. This change could be related to a psychological strengthening of female students and, in addition, that the students had visited female patients.

Analysis of the predominant aspects of the Draw-a-Person test allowed for the following interpretations ${ }^{12,14}$ : despite being afraid of facing a PALS, students became adjusted to the environment, able to control their anxiety and insecurity, and accept social and moral laws, while demonstrating an in-depth perspective of the environment/patients. The students saw the PALS as global individuals but were able to detach a possible identification with the patient and, thus, expressed their own identity.

\section{Desiderative questionnaire}

Type and sequence of answers: a predominance of the animal kingdom in the first positive choice found in our research has also been reported by other authors working with groups of medical and nursing students, as well as with children, children following liver transplantation, and hospitalized and non-hospitalized neuropsychiatry adolescent patients ${ }^{19,20,37,38}$. While the animal "dog" appears as the most frequent choice among adults, adolescents and healthcare professionals usually have a predominance of the animal "bird"20,21,22. Birds and dogs were, respectively, the most frequent wild and domestic animals chosen by a group of nursing students due to their "freedom" in the first case and to their "good life" in the second ${ }^{37}$. The shift to the vegetal "tree" as a common answer in the positive choices after visits has not previously been reported, despite this being the second most frequent answer in the positive choices in some studies; this answer could point to the strength necessary to deal with suffering ${ }^{17,20,22}$.

Guimarães and Pasian ${ }^{19,20}$ showed that healthy adolescents have one or more failures to answer the Desiderative Questionnaire, which may be related to a pathological characteristic traditionally attributed to this aspect and could be indicative of the teenagers' process of adaptation to reality $^{19,20}$. Failure decreased in the post visit, which suggests that the students had overcome their conflicts due to the increase in both personal and professional experience ${ }^{10,19,20}$.

Answer time: Long reaction times are associated with difficulty in self-organization and short reaction times, with avoidance of anxiety ${ }^{10,22,39}$. The students' short reaction times may be related to impulsive behavior and anxiety at the beginning of the test. The significant reduction of the answer time found in psychology students after visits indicates increasing anxiety about visits. Psychology students were able to sustain the anguish at the pre-visit but not at the post-visit time. It is possible that the students believed they had sufficient theoretical instruments to deal with the care of a PALS, but 


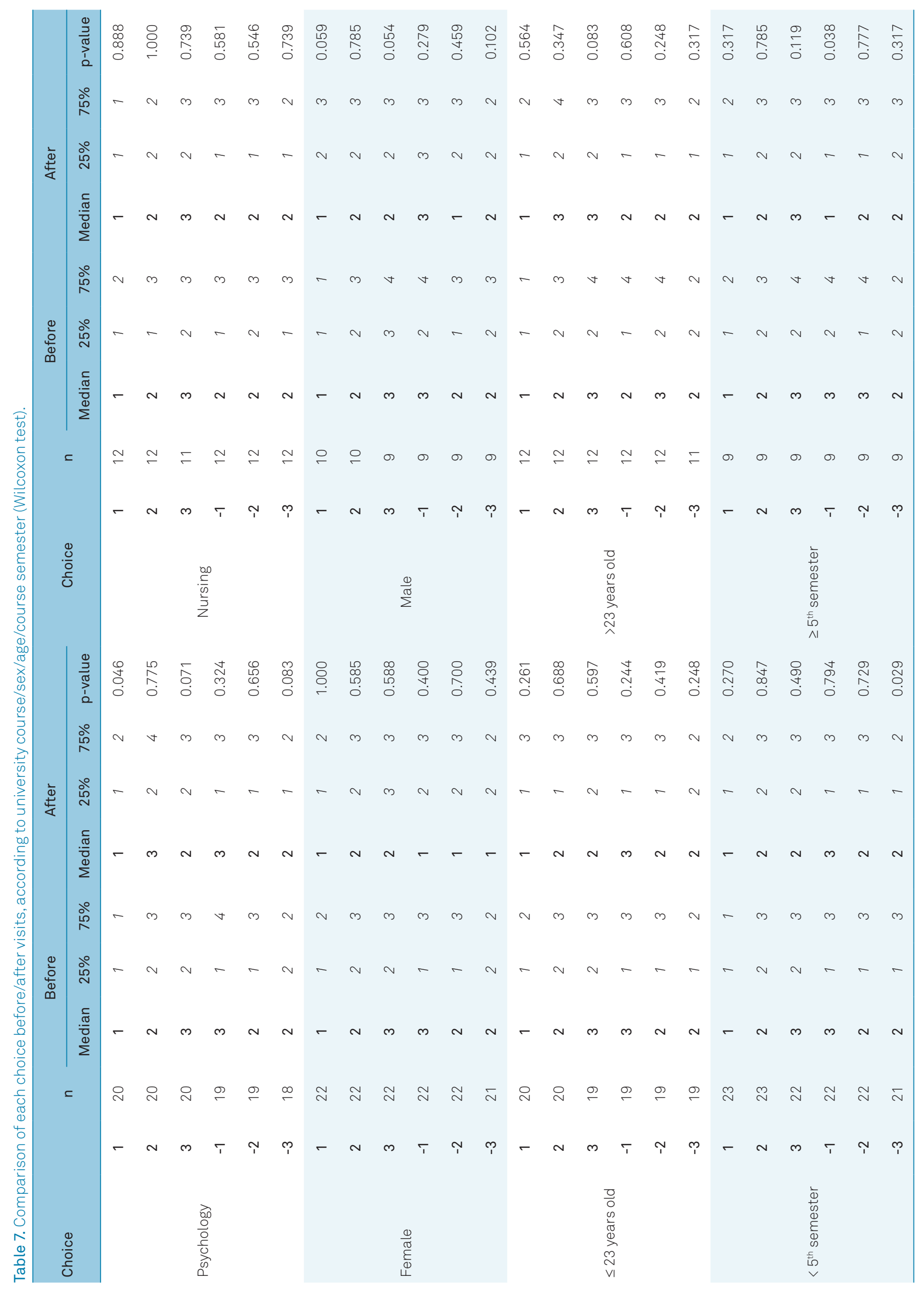


the reality was beyond their resources; the opposite may have occurred with nursing students.

Answers versus variables: Some subgroups of students presented a significant deviation from the expected ideal answer, and additional attention/support may be necessary for those specific subgroups/moments. In the nursing course subgroup, pre-visit anxiety was initially not sustained by students, but their psychological condition improved in the post-visit evaluation, with better control of anxiety. In the male sex subgroup, after the visits, despite none of the students dropping out of the study, their anxiety increased in the post-visit evaluation. In the psychology course subgroup, after the visits, as noted before, there was an increase in anxiety as demonstrated by the significant reduction in the answer time and worsening in choice +1 . Similar to the visit to a PALS, the beginning of their practical internship triggers a high level of anxiety in psychology students ${ }^{40}$. In the students aged $\leq 23$ years old subgroup, after the visits, the younger students were not able to cope with matters related with death. David ${ }^{37}$ did not find statistically significant differences between first year or junior (third year) medical students but had not researched older students ${ }^{37}$.

Students in the fourth semester or lower showed a worsening in the choice -3 , whereas those in the fifth semester or higher showed an improvement in the choice -1 . At this point in the course, students are usually closer to their professional/ethical responsibilities as future professionals, which is a cause of anxiety and insecurity but also of positive psychological strengthening.

The inversion in the first negative choice found in our study in the whole sample (i.e., the inanimate objects predominating over the animal kingdom), both before and after visits, has not been described in first-year university students ${ }^{17}$. Interestingly, some subgroups did not experience this inversion, which could indicate better adequacy to reality and logical functioning when faced with stressful situations such as ALS assistance; in general, these were the same groups that presented the expected ideal answer.

Unfortunately, it was not possible in this study to increase the follow-up time due to patient deaths and the students' semester ending, which led to a change in the workload that prevented continuity of visits and psychological follow-up. It would be desirable to perform additional studies with a greater number of students and PALS, including comparisons among groups with different forms of ALS (possible, probable and definitive). Moreover, future studies could focus on an extended follow-up, with a greater number of visits, to better evaluate the data from the Draw-a-Person test, the Desiderative Questionnaire, and the McGill Quality of Life Questionnaire. In particular, an extended follow up could possibly detect a significant increase in psychological wellbeing.

In conclusion, this study suggests that students' visits to PALS may contribute to the maintenance of their QOL. The emotional support provided by students mayhave contributed to the psychological well-being of the PALS. Additionally, visits with psychological support for the students seem safe and may contribute to the psychological maturation of these future professionals. All of the preparation undertaken by the students during the process contributed to the development of their necessary perception of and care towards the patient. Future research should focus on the subgroups that showed weakness in the analyses performed in this study and develop additional strategies to provide support for these subgroups.

\section{Acknowledgments}

We thank Dr. Robin Cohen and Dr. Balfour Mount for their kind permission to use the McGill Quality of Life Questionnaire.

\section{References}

1. Pagnini F. Psychological wellbeing and quality of life in amyotrophic lateral sclerosis: a review. Int J Psychol. 2013;48(3):194-205. https://doi.org/10.1080/00207594.2012.691977

2. Albert SM, Rabkin JG, Del Bene ML, Tider T, O'Sullivan I, Rowland LP, et al. Wish to die in end-stage ALS. Neurology. 2005 Jul;65(1):68-74. https://doi.org/10.1212/01.wnl.0000168161.54833.bb

3. Boerner K, Mock SE. Impact of patient suffering on caregiver well-being: the case of amyotrophic lateral sclerosis patients and their caregivers. Psychol Health Med. 2012;17(4):457-66. https://doi.org/10.1080/13548506.2011.613942

4. Ganzini L, Johnston WS, McFarland BH, Tolle SW, Lee MA. Attitudes of patients with amyotrophic lateral sclerosis and their care givers toward assisted suicide. N Engl J Med. 1998 Oct;339(14):967-73. https://doi.org/10.1056/NEJM199810013391406

5. Lillo P, Mioshi E, Hodges JR. Caregiver burden in amyotrophic lateral sclerosis is more dependent on patients' behavioral changes than physical disability: a comparative study. BMC Neurol. 2012 Dec;12(1):156. https://doi.org/10.1186/1471-2377-12-156
6. Maessen M, Veldink JH, Berg LH, Schouten HJ, Wal G, Onwuteaka-Philipsen BD. Requests for euthanasia: origin of suffering in ALS, heart failure, and cancer patients. J Neurol. 2010 Jul;257(7):1192-8. https://doi.org/10.1007/s00415-010-5474-y

7. Roy-Bellina S, Camu W. [Psychological treatment for the patient and caregivers during the course of amyotrophic lateral sclerosis]. Rev Neurol (Paris). 2006 Jun;162 Spec No 2:4S295-4S300. French.

8. Fussellier, M. [Caring for a patient with amyotrophic lateral sclerosis: the patient's and the caregiver's experience]. Rev Neurol (Paris). 2006 Jun;162 Spec No 2:4S209-4S214. French.

9. Kim D, Teo A, Mulle AM. The Stanford giving tree: ALS/MND patients receive home assistance from university student volunteers. Abstracts from the $12^{\circ}$ International Symposium on Amyotrophic Lateral Sclerosis/Motor Neuron Disorders; 18-20 November 2001; Oakland, USA. Amyotroph Lateral Scler Other Motor Neuron Disord. 2001;2 Suppl 2:69-70.

10. Klein M. Envy and gratitude, and other works, 1946-1963. New York: The Free Press; 1975. 
11. Cohen SR, Mount BM, Bruera E, Provost M, Rowe J, Tong K. Validity of the McGill Quality of Life Questionnaire in the palliative care setting: a multi-centre Canadian study demonstrating the importance of the existential domain. Palliat Med. 1997 Jan;11(1):3-20. https://doi.org/10.1177/026921639701100102

12. Machover K. Personality projection in the drawing of a human figure: a method of personality investigation. Springfield: Charles C Thomas; 1978.

13. Guillemin M. Understanding illness: using drawings as a research method. Qual Health Res. 2004 Feb;14(2):272-89. https://doi.org/10.1177/1049732303260445

14. Buck JN. House-tree-person technique: revised manual. Los Angeles: Western Psychological Services; 1970

15. Dmitruk VM. Situational variables and performance on Machover's figure-drawing test. Percept Mot Skills. 1972 Oct;35(2):489-90. https://doi.org/10.2466/pms.1972.35.2.489

16. Brêga FM, Frazatto L, Loureiro SR. [Patients with paranoid characteristics - defensive functioning]. Psico-USF. 2001;6:85-94. Portuguese.

17. Bunchaft $G$, Vasconcellos VL. [Standardization of the Pigem's Test in the context of transactional analysis: first results]. Psicol, Teor Pesqui. 2001;17(1):19-25. Portuguese. https://doi.org/10.1590/S0102-37722001000100005

18. Córdoba J, Pigem JM, El Gurria FJ. [The desiderative expression "test" in the study of the personality]. Rev Psicol Gen Aplicada. 1951;6:121-30.

19. Guimarães NM, Pasian SR, Barbieri V. [The symbolic equation as a therapeutical resource: Contributions for the analysis of the desiderative questionnaire]. Paidéia (Ribeirão Preto). 2006;16(35):365-76. Portuguese. https://doi.org/10.1590/S0103-863X2006000300007

20. Guimarães NM, Pasian SR. [Adequacy to Reality of Adolescents: informative possibilities of the Desiderative Questionnaire]. Psicol, Teor Pesqui. 2009;25(3):347-55. Portuguese. https://doi.org/10.1590/S0102-37722009000300008

21. Medeiros D, Pinto AA Junior. [A study on the egoic structure of hospitalists through desiderative questionnaire]. Rev SBPH (Belo Horizonte). 2006;9:91-9. Portuguese.

22. Tardivo LS. [The structuring of the ego: the study of the degree of structuring of the ego of health professionals through the Desiderative Questionnaire]. Psic Revista de Psicologia da Vetor Editora. 1999;1:28-34.

23. Van Krevelen DA. The use of Pigem's test with children.J Proj Tech. 1956 Jun;20(2):235-42. https://doi.org/10.1080/08853126.1956.10380694

24. Dietrich-Neto F, Callegaro D, Dias-Tosta E, Silva HA, Ferraz ME, Lima JM, et al. Amyotrophic lateral sclerosis in Brazil: 1998 national survey. Arq Neuropsiquiatr. 2000 Sep;58 3A:607-15. https://doi.org/10.1590/S0004-282X2000000400002

25. Jenkinson C, Swash M, Fitzpatrick R. The European amyotrophic lateral sclerosis health profile study. J Neurol Sci. 1998 Oct;160 Suppl 1:S122-6. https://doi.org/10.1016/S0022-510X(98)00210-X

26. Nelson ND, Trail M, Van JN, Appel SH, Lai EC. Quality of life in patients with amyotrophic lateral: Perceptions, coping resources, and illness characteristics. J Palliat Med. 2003 Jun;6(3):417-24. https://doi.org/10.1089/109662103322144736 •

27. Goldstein LH, Atkins L, Landau S, Brown RG, Leigh PN. Longitudinal predictors of psychological distress and self-esteem in people with ALS. Neurology. 2006 Nov;67(9):1652-8. https://doi.org/10.1212/01.wnl.0000242886.91786.47

28. Pagnini F, Lunetta C, Rossi G, Banfi P, Gorni K, Cellotto $\mathrm{N}$, et al. Existential well-being and spirituality of individuals with amyotrophic lateral sclerosis is related to psychological well-being of their caregivers. Amyotroph Lateral Scler. 2011 Mar;12(2):105-8. https://doi.org/10.3109/17482968.2010.502941

29. Brocq H1, Soriani MH, Desnuelle C. [Psychological reactions to the announcement of a severe disease diagnosis: The amyotrophic lateral sclerosis example]. Rev Neurol (Paris). 2006 Jun;162 Spec No 2:4S104-7. French.

30. Calzada Sierra DJ. [Bioethical considerations in the approach to patients with amyotrophic lateral sclerosis]. Rev Neurol. 2001 May;32(10):952-7. Spanish. https://doi.org/10.33588/rn.3210.2000463

31. Kluge EH. Doctors, death and Sue Rodriguez. CMAJ. 1993 Mar;148(6):1015-7.

32. Olsson AG, Markhede I, Strang S, Persson LI. Differences in quality of life modalities give rise to needs of individual support in patients with ALS and their next of kin. Palliat Support Care. 2010 Mar;8(1):75-82. https://doi.org/10.1017/S1478951509990733

33. Pagnini F, Rossi G, Lunetta C, Banfi P, Corbo M. Clinical psychology and amyotrophic lateral sclerosis. Front Psychol. 2010 Jul;1:33. https://doi.org/10.3389/fpsyg.2010.00033

34. Dyrbye LN, Thomas MR, Shanafelt TD. Medical student distress: causes, consequences, and proposed solutions. Mayo Clin Proc. 2005 Dec;80(12):1613-22. https://doi.org/10.4065/80.12.1613

35. Airoldi M, Garzaro M, Raimondo L, Pecorari G, Giordano C, Varetto $A$, et al. Functional and psychological evaluation after flap reconstruction plus radiotherapy in oral cancer. Head Neck. 2011 Apr;33(4):458-68. https://doi.org/10.1002/hed.21471

36. Aronoff DN, McCormick NB. Sex, sex role identification, and college students' projective drawings. J Clin Psychol. $1990 \mathrm{Jul}$;46(4):460-6. https://doi.org/10.1002/1097-4679(199007)46:4<460::AIDJCLP2270460414>3.0.C0;2-S

37. David, H.P. Brief, unstructured items: the projective question. J Proj Tech.1955;19(3):292:300. https://doi.org/10.1080/08853126.1955.10380638

38. Zamberlan KE. Quality of life in school-age children following liver transplantation. Matern Child Nurs J. 1992;20(3-4):167-229.

39. Freud S. The complete psychological works of Sigmund Freud. 2nd ed. New York: W. W. Norton; 1987.

40. González A, Paoloni V, Donolo D, Rinaudo C. Motivational and emotional profiles in university undergraduates: a self-determination theory perspective. Span J Psychol. 2012 Nov;15(3):1069-80. https://doi.org/10.5209/rev_SJOP.2012.v15.n3.39397 